\title{
unindra a duconowics

The Effect of Learning Readiness and Learning Motivation on Learning Outcomes in Social Studies Subjects for Class VIII Students at SMP Negeri 1 Tarumajaya Bekasi

Pengaruh Kesiapan Belajar dan Motivasi Belajar terhadap Hasil Belajar pada Mata Pelajaran IPS Siswa Kelas VIII di SMP Negeri 1 Tarumajaya Bekasi

\begin{tabular}{l}
\hline Author \\
\hline Oyin Supriyatna \\
Universitas Indraprasta PGRI \\
Jakarta \\
Adeng Hudaya \\
Universitas Indraprasta PGRI \\
Jakarta \\
Abdul Munir \\
Universitas Indraprasta PGRI \\
Jakarta
\end{tabular}

\section{Duconomics} Sci-meet

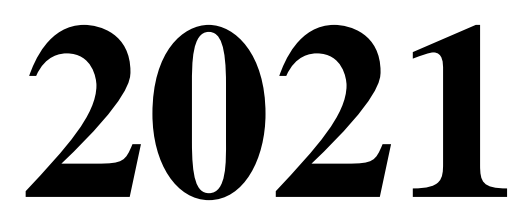

VOLUME 1

JULI

Page

$435-444$

DOI

10.37010/duconomics.v1.5497

Corresponding Author:
Abstract

The purpose of this study was to determine the effect of learning readiness and learning motivation together on the learning outcomes of social studies subjects for class VIII students at SMPN 1 Tarumajaya Bekasi. In addition, researchers hope that readers, especially schools, can pay attention to student learning readiness and student motivation to improve learning outcomes. The method used in analyzing this research is a quantitative research method. The population in this study was 400 of all class VIII students for the 2020/2021 academic year and a sample of 92 students. Through correlation calculations obtained rx $1 y 0.740$ and rx2y 0.748, which means there is a high correlation between X1 to Y and X2 to Y. Analysis of the coefficient of determination obtained 0.900 This shows that the contribution of variables X1 (Readiness to Learn) and X2 (Learning Motivation) to variable $Y$ (Results learning) by $90 \%$ and the remaining $10 \%$ is determined by other factors not examined in this study. The multiple linear regression coefficient shows the constant value $a=11.726 \mathrm{bl}=0.417$ and $b 2=0.445$. Testing the statistical hypothesis obtained by the results obtained $F$ arithmetic $>F$ table $(401.052>3.100)$ shows that simultaneously

Learning Readiness and Learning Motivation together affect Learning Outcomes. While the variable t test X1 t count $=16.106>t$ table $=1.990$. Shows that there is an effect of learning readiness on the learning outcomes of class VIII students at SMPN 1 Tarumajaya Bekasi. And the t-test of the X2 variable tcount $=17.617>$ ttable $=1.990$. Shows that there is an influence of learning motivation on the learning outcomes of class VIII students at SMPN 1 Tarumajaya Bekasi

Keywords

readiness to learn, motivation to learn, learning outcomes

Abstrak

Tujuan penelitian ini adalah untuk mengetahui pengaruh kesiapan belajar dan motivasi belajar secara berasama-sama Terhadap Hasil Belajar Mata

Pelajaran IPS Siswa Kelas VIII di SMPN 1 Tarumajaya Bekasi. Selain itu peneliti berharap agar pembaca terutama pihak sekolah dapat memperhatikan kesiapan belajar siswa dan Motivasi belajar siswa untuk meningkatkan Hasil

Belajar. Metode yang digunakan dalam menganalisis penelitian ini adalah

metode penelitian kuantitatif. Populasi dalam penelitian ini adalah 400 dari seluruh peserta didik kelas VIII Tahun Ajaran 2020/2021 dan sampel sebanyak 92 peserta didik. Melalui perhitungan korelasi diperoleh rx1 y 0.740 dan rx2y 0.748 yang berarti terdapat korelasi yang tinggi antara X1 terhadap

Y serta X2 terhadap Y. Analisis koefisien determinasi diperoleh 0.900 ini menunjukkan bahwa kontribusi variabel X1 (Kesiapan Belajar) dan X2

(Motivasi Belajar) terhadap variabel Y (Hasil Belajar) sebesar 90\% dan sisanya $10 \%$ ditentukan oleh faktor-faktor lain yang tidak diteliti pada penelitian ini. Koeisien regresi linier berganda menunjukan nilai konstanta $\mathrm{a}=11,726 \mathrm{~b} 1=0.417$ dan $\mathrm{b} 2=0,445$. Pengujian hipotesis statistik yang diperoleh hasil diperoleh F hitung > F tabel $(401,052>3,100)$ menunjukan bahwa secara simultan Kesiapan Belajar dan Motivasi Belajar bersama-sama berpengaruh terhadap Hasil Belajar. Sedangkan uji t variabel X1 $\mathrm{t}$ hitung = $16,106>t$ tabel $=1,990$. Menunjukkan bahwa ada Pengaruh Kesiapan Belajar terhadap Hasil Belajar siswa kelas VIII di SMPN 1 Tarumajaya Bekasi. Serta uji t variabel X2 thitung $=17,617>$ ttabel $=1,990$.

Menunjukkan bahwa ada Pengaruh Motivasi Belajar terhadap Hasil Belajar siswa kelas VIII di SMPN 1 Tarumajaya Bekasi

\begin{tabular}{l}
\hline Kata kunci \\
\hline kesiapan belajar, motivasi belajar, hasil belajar
\end{tabular}




\section{PENDAHULUAN}

Pendidikan merupakan upaya sadar manusia dalam rangka merengkuh masa depan yang lebih baik seperti yang tertuang dalam tujuan pendidikan nasional Indonesia. Lebih jauh tujuan pendidikan ialah proses pembentukan dan pengubahan perilaku yang diinginkan dan pengurangan atau pelenyapan perilaku yang diinginkan. Pendidikan menjadi satu dengan proses pertumbuhan.

Sedangkan fungsi dari pendidikan juga tertuang dalam Undang-Undang No.2 tahun 2013 pasal 3 yang berbunyi: Pendidikan nasional berfungsi mengembangkan dan membentuk watak serta peradaban bangsa yang bermartabat dalam rangka mencerdaskan kehidupan bangsa, bertujuan untuk berkembangnya potensi peserta didik agar menjadi manusia yang beriman dan bertakwa kepada Tuhan Yang Maha Esa, berakhlak mulia, sehat, berilmu, cakap, kreatif, mandiri dan menjadi warga negara yang demokratis serta bertanggung jawab. Indikator pendidikan yang baik ialah tercapainya seluruh rangkaian pembelajaran seperti yang tertulis pada fungsi pendidikan dalam Undang-Undang. Pendidikan yang kurang baik menyebabkan pembangunan manusia yang tertinggal.

Menurut HDI (Human Development Indeks) laporan dari UNDP yang dikembangkan oleh Amartya Sen \& Mahbub U1 Haq pada tahun 1990, memperlihatkan bahwa Indonesia pada tahun 2019 menduduki peringkat 111. Pada peringkat ini, nilai HDI yang dicatatkan adalah 0,707, dengan tingkat harapan hidup 71,5, jumlah tahun pendidikan yang diharapkan 12,9, ratarata tahun pendidikan yang ditempuh 8 tahun atau setara dengan SMP Kelas 8, dan pendapatan perkapita 11.256. Meskipun oleh UNDP Indonesia baru saja dikelompokkan menjadi negara dengan HDI tinggi dan tidak ada peningkatan dalam ranking, tetap saja kondisi ini patut menjadi perhatian kita, karena kita masih tertinggal dengan beberapa negara sahabat.

Jika kita pelajari lebih lanjut indikator yang ada di masing-masing negara sahabat, faktor pendidikan yang ada di Indonesia berkontribusi cukup besar untuk nilai yang didapatkan. Bila kita lihat sebagai contoh Malaysia, jumlah tahun pendidikan yang diharapkan 13,5, dan ratarata tahun pendidikan yang ditempuh 10,2 tahun hal ini masih lebih tinggi daripada Indonesia. Dengan analisa sederhana kita bisa mempelajari dan berkesimpulan bahwa tingginya indeks pendidikan akan secara otomatis meningkatkan produktifitas masyarakatnya sehingga GNI per kapita menjadi tinggi, dan secara terus menerus pula akan meningkatkan tingkat harapan hidup karena masyarakatnya yang lebih sadar akan kesehatan.

Berbagai upaya pemerintah dilakukan untuk perbaikan pendidikan di Indonesia, baik berupa penyederhanaan kurikulum, Administrasi yang tidak membebani kegiatan Belajar Mengajar Guru, serta berbagai stimulus agar guru dan siswa melakukan perbaikan diri dan bersemangat dalam melaksanakan kegiatan Belajar Mengajar.

SMPN 1 Tarumajaya Bekasi sebagai salah satu institusi pendidikan pemerintah dibawah naungan Dinas Pendidikan Pemerintah Kabupaten Bekasi merupakan institusi ujung tombak yang langsung bersentuhan dengan siswa sebagai input pendidikan. Ketercapaian belajar yang memuaskan dapat tergambarkan dalam bentuk Hasil Belajar siswa dalam pembelajaran. Hasil siswa dalam bentuk pengetahuan dan keterampilan diukur dan diujikan dan diperoleh angkaangka sebagai nilai kemampuan tersebut.

Berdasarkan observasi awal penelitian, penulis menemukan banyaknya nilai Ulangan Tengah Semester dan Ulangan Semester siswa yang dibawah KKM. Rata-rata nilai kelas adalah 69 masih rendah dibandingkan dengan KKM IPS kelas VIII di SMPN 1 Tarumajaya Bekasi yakni 74.

Motivasi siswa dalam pelajaran IPS di SMPN 1 Tarumajaya Bekasi juga masih relatif rendah. Hal ini ditunjukkan dari hasil wawancara guru IPS kelas VIII.2 yang berjumlah 40 siswa. Motivasi yang rendah meliputi, antusias siswa pada saat pelaksanaan pembelajaran secara daring (online) dalam bertanya sebanyak 8 siswa (20\%), antusias siswa dalam menjawab pertanyaan sebanyak 12 siswa (30\%). Berdasarkan catatan petugas perpustakaan pun halnya 
demikian, sebelum pandemi covid-19 dari 400 siswa kelas VIII dalam satu bulan hanya 50 siswa yang aktif meminjam buku teks selain buku pelajaran.

Selain itu, ketiadaan sarana lab IPS juga terindikasi menjadi penyebab rendahnya Hasil siswa. Lab IPS dibutuhkan agar siswa mengenal lebih dekat dengan materi pembelajaran IPS dengan praktek dan media yang lebih intensif. Guru juga mengeluhkan siswa tidak siap melaksanakan pembelajaran baik daring maupun tatap muka di sekolah, banyak siswa yang tidak membekali diri dengan membaca di rumah sebelum pembelajaran dimulai, dan laporan dari orang tua bahwa anak-anak mereka lebih sering bermain game di rumah dibandingkan membaca buku dan kegiatan literasi. Permasalahan ini harus segera diselesaikan dan dicarikan upaya penelitian untuk mengetahui permasalahan dan alternatif solusi agar Hasil siswa di SMPN 1 Tarumajaya Bekasi dapat terus sesuai harapan dan meningkat.

\section{Hasil Belajar}

Rusman menyatakan bahwa (2017:129) "Hasil belajar adalah sejumlah pengalaman yang diperoleh siswa yang mencakup ranah kognitif, afektif, dan psikomotorik". Sedangkan Menurut Supardi (2012:194), "Hasil belajar adalah pola-pola perubahan tingkah laku seseorang yang meliputi aspek kognitif, afektif, dan psikomotorik". Sedangkan menurut Jihad, dkk. (2012:14) "Hasil belajar adalah kemampuan yang diperoleh anak setelah melalui kegiatan belajar".

Berdasarkan pengertian hasil belajar menurut para ahli di atas, penulis dapat merumuskan bahwa hasil belajar adalah sejumlah pengalaman dari sebuah proses belajar mengajar yang mencakup ranah kognitif, afektif, dan psikomotorik untuk mencapai tujuan pendidikan pada siswa melalui proses kegiatan belajar mengajar.

Untuk mendapatkan hasil belajar yang maksimal, tentu seorang siswa harus melakukan usaha yang maksimal, tentu usaha maksimal ini harus didukung dengan faktor-faktor yang baik. Menurut Slameto (2010:54) faktor-faktor yang mempengaruhi hasil belajar antara lain:

1. Faktor internal, meliputi:

a) Faktor jasmaniah: kesehatan dan cacat tubuh.

b) Faktor psikologis: intelegensi, perhatian, minat dan bakat, motivasi, kematangan dan kesiapan.

c) Faktor kelelahan.

2. Faktor eksternal, meliputi:

a) Faktor keluarga: cara orang tua mendidik, relasi antar keluarga, suasana rumah, keadaan ekonomi keluarga, pengertian orang tua dan latar belakang kebudayaan.

b) Faktor sekolah, meliputi: metode mengajar, kurikulum, relasi guru dengan siswa, relasi siswa dengan siswa, disiplin sekolah, alat pengajaran, waktu sekolah, keadaan gedung.

3. Faktor masyarakat, meliputi: kegiatan siswa dalam masyarakat, media massa, teman bergaul, dan bentuk kehidupan masyarakat lainnya.

Faktor di atas dapat menimbulkan hasil belajar siswa yang berbeda-beda. Interaksi antara motivasi belajar dan kesiapan belajar dapat meningkatkan hasil belajar jika dimanfaatkan secara optimal. Misalnya ketika siswa memiliki kecerdasan dalam pembelajaran tetapi tidak didukung dengan kesiapan belajar serta motivasi yang timbul baik dari dalam individu atau dari luar individu maka hasil yang akan dicapai tidak akan maksimal.

\section{Kesiapan Belajar}

Al-Farabi (2018:182) menyimpulkan dari kajian terhadap beberapa surah Al-Qur'an bahwa kesiapan belajar terwujud dalam beberapa konsep meliputi:

1. Kesiapan Belajar orang dewasa sangat ditentukan oleh niat belajar karena Allah

2. Kesiapan menerima pelajaran baru memungkinkan terwujud setelah diberikan bimbingan terlebih dahulu. 
Merdeka Belajar dan Tantangan Ekonomi dalam Menyongsong Era Society 5.0

3. Materi pelajaran yang telah ditelaah dan didemonstrasikan bersama, sangat mendukung pembelajar dewasa untuk menerima pelajaran berikutnya

4. Kesiapan belajar berikutnya adalah ditandai dengan kesiapan mengamalkan materi pelajaran yang telah diperoleh sebelumnya.

5. Kesiapan belajar dapat dimotivasi dengan pengenalan terhadap potensi-potensi diri.

6. Kesiapan belajar dapat dimotivasi dengan meningkatkan intensitas belajar melalui aktivitas gemar membaca dan menelaah.

7. Kesiapan belajar lebih maksimal jika didukung oleh kemampuan menulis

8. Kesiapan belajar terwujud melalui keistikamahan dalam tekad, sikap, dan perbuatan.

9. Kesiapan belajar yang didasarkan istikamah memerlukan perenungan dan kesadaran untuk berbuat yang terbaik serta pengendalian emosional yang stabil.

10. Kesiapan belajar yang didasarkan istikamah melahirkan kekuatan mental pembelajar dewasa untuk gigih dan sabar dalam menghadapi kesulitan dan tantangan.

11. Kesiapan belajar yang didasarkan istikamah tercermin dalam kesuksesan menguasai ilmu, keterampilan, dan akhlak.

Menurut Sutiah (2016:14) Kesiapan belajar merupakan kondisi fisik-psikis (jasmani-mental) individu yang memungkinkan subjek dapat melakukan proses belajar. Sedangkan menurut Bruner Kesiapan terdiri atas penguasaan dan keterampilan-keterampilan yang lebih sederhana yang dapat mengijinkan seseorang untuk mecapai keterampilan-keterampilan yang lebih tinggi.

Kesiapan belajar ini juga menyangkut kematangan pertumbuhan fisik dan psikis, intelegensia, latar belakang pengalaman, hasil belajar yang baku, motivasi, persepsi dan faktor-faktor yang memungkinkan seseorang dapat belajar. Proses belajar sangat dipengaruhi oleh kesiapan individu sebagai subjek yang melakukan kegiatan belajar.

Adapun prinsip dalam pembelajaran yang bertumpu pada konsep kesiapan belajar diantaranya:

1. Individu akan dapat belajar dengan baik apabila tugas yang diberikan kepadanya sesuai dengan kesiapan (kematangan usia, kemampuan, minat, dan latar belakang pengalamannya)

2. Kesiapan belajar harus dikaji lebih dulu untuk memperoleh gambaran kesiapan belajar peserta didik dengan jalan menguji kesiapan atau kemampuan.

3. Jika individu kurang siap melaksanakan suatu tugas belajar, maka akan menghambat proses pengaitan pengetahuan baru kedalam struktur kognitif yang dimilikinya.

4. Kesiapan belajar mencerminkan jenis dan taraf kesiapan untuk menerima suatu yang baru dalam membentuk dan mengembangkan kemampuan lebih matang.

5. Bahan dan tugas-tugas belajar akan sangat baik kalau divariasi sesuai dengan faktor kesiapan kognitif, afektif, dan psikomotorik peserta didik yang akan belajar. (Sutiah, 2016:14).

Slameto (2010:59) yang mengemukakan bahwa kesiapan perlu diperhatikan dalam proses belajar karena saat siswa sudah memiliki persiapan belajar maka hasil belajarnya akan lebih baik. Kesiapan diperlukan dalam proses belajar mengajar karena dalam kondisi siap siswa akan cenderung lebih mudah untuk mengikuti pembelajaran.

\section{Motivasi Belajar}

Menurut Hamzah B. Uno (2011: 23) "motivasi belajar adalah dorongan internal dan eksternal pada siswa yang sedang belajar untuk mengadakan tingkah laku, pada umumnya dengan beberapa indikator atau unsur-unsur yang mendukung. Indikator-indikator tersebut, antara lain: adanya hasrat dan keinginan berhasil, dorongan dan kebutuhan dalam belajar, harapan dan cita-cita masa depan, penghargaan dalam belajar, dan lingkungan belajar yang kondusif."

Selain itu, Winkel (2005: 160), menyebutkan motivasi belajar adalah keseluruhan daya penggerak psikis didalam siswa yang menimbulkan kegiatan belajar itu demi mencapai suatu tujuan. Sejalan dengan pendapat di atas, Sardiman A. M (2007: 75), menjelaskan motivasi 
belajar adalah seluruh daya penggerak didalam diri siswa yang menimbulkan kegiatan belajar yang menjamin kelangsungan dari kegiatan belajar yang memberikan arah pada kegiatan belajar sehingga tujuan yang dikehendaki oleh subjek belajar itu dapat dicapai."

Dari beberapa pendapat di atas dapat disimpulkan bahwa motivasi belajar adalah seluruh daya penggerak psikis yang ada dalam diri individu siswa yang dapat memberikan dorongan untuk belajar demi mencapai tujuan dari belajar tersebut.

\section{Prinsip-prinsip Motivasi Belajar}

Mulyasa (2005: 114-115), menyebutkan bahwa prinsip yang dapat diterapkan untuk meningkatkan motivasi belajar adalah sebagai berikut:

1. Peserta didik akan lebih giat apabila topik yang akan dipelajari menarik dan berguna bagi dirinya.

2. Tujuan pembelajaran disusun secara jelas dan diinformasikan kepada peserta didik agar mereka mengetahui tujuan belajar tersebut.

3. Peserta didik selalu diberi tahu tentang hasil belajarnya.

4. Pemberian pujian dan reward lebih baik daripada hukuman, tapi sewaktu-waktu hukuman juga diperlukan.

5. Memanfaatkan sikap, cita-cita dan rasa ingin tahu peserta didik.

6. Usahakan untuk memperhatikan perbedaan setiap peserta didik, misalnya perbedaan kemauan, latarbelakang dan sikap terhadap sekolah atau subjek tertentu.

7. Usahakan untuk memenuhi kebutuhan peserta didik dengan selalu memperhatikan mereka dan mengatur pengalaman belajar yang baik agar siswa memiliki kepuasan dan penghargaan serta mengarahkan pengalaman belajarnya ke arah keberasilan, sehingga memiliki kepercayaan diri dan tercapainya prestasi belajar.

Dari uraian di atas, dapat disimpulkan bahwa ada beberapa prinsip-prinsip untuk meningkatkan motivasi belajar siswa yaitu jika topik yang akan dipelajari menarik dan berguna, tujuan pembelajaran pun disusun secara jelas, hasil belajar peserta didik harus diberitahukan, pemberian reward bagi yang berprestasi, memanfaatkan sikap-sikap, citacita dan rasa ingin tahu peserta didik, memperhatikan perbedaan mereka, dan berusaha memenuhi kebutuhan peserta didik dengan memperhatikannya.

Faktor-faktor yang Mempengaruhi Motivasi Belajar Menurut Slameto (2010: 26), motivasi belajar dipengaruhi oleh tiga komponen, yaitu:

1. Dorongan kognitif, yaitu kebutuhan untuk mengetahuhi, mengerti, dan memecahkan masalah. Dorongan ini timbul di dalam proses interaksi antara siswa dengan tugas/masalah.

2. Harga diri, yaitu ada siswa tertentu yang tekun belajar dan melaksanakan tugas-tugas bukan terutama untuk memperoleh pengetahuan atau kecakapan, tetapi untuk memperoleh status dan harga diri.

3. Kebutuhan berafiliasi, yaitu kebutuhan untuk menguasai bahan pelajaran/ belajar dengan niat guna mendapatkan pembenaran dari orang lain/ teman-teman. Kebutuhan ini sukar dipisahkan dengan harga diri.

\section{METODE}

Metode yang digunakan dalam penelitian ini adalah metode deskriptif dengan pendekatan kuantitatif, yaitu mengungkapkan pengaruh antar variabel dan dinyatakan dalam angka serta menjelaskannya dengan membandingkan dengan teor-teori yang telah ada dan menggunakan teknik analisis data sesuai dengan variabel dalam penelitian. Jumalah sampel sebanyak 92 siswa dengan teknik pengumpulan data menggunakan kuesioner. Sedangakan 


\section{0}

Merdeka Belajar dan Tantangan Ekonomi dalam Menyongsong Era Society 5.0 teknik analisis data menggunakan regresi linier berganda, korelasi product moment dan uji hipotesis menggunakan uji $\mathrm{F}$ dan uji $\mathrm{t}$.

\section{HASIL DAN PEMBAHSAN \\ Koefisien Regresi Linier Berganda}

Untuk mengetahui hubungan Kesiapan Belajar dan Motivasi Belajar siswa dengan hasil belajar siswa digunakan analisis Regresi Linier Berganda. Berdasarkan hasil perhitungan Regresi dengan menggunakan program perhitungan statistik SPSS diperoleh hasil sebagai berikut:

Tabel Koefisien Regresi

\begin{tabular}{clccc}
\hline & Model & \multicolumn{2}{c}{$\begin{array}{c}\text { Unstandardized } \\
\text { Coefficients }\end{array}$} & $\begin{array}{c}\text { Standardized } \\
\text { Coefficients }\end{array}$ \\
& B & Std. Error & Beta \\
\hline 1 & (Constant) & 11.726 & 2.461 & \\
& KESIAPAN_BELAJA & .417 & .026 & .564 \\
& R & & & .617 \\
& MOTIVASI_BELAJA & .445 & .025 &. \\
& R & & & \\
\end{tabular}

Dependent Variable: HASIL_BELAJAR

Dari tabel di atas maka persamaan Regresi Linier Berganda konstanta $a=11,726$ dan $b_{1}=$ 0,417 serta $b_{2}=0,445$. Dengan memasukkan a dan $b$ ke dalam persamaan regresi $\mathrm{Y}, \mathrm{X} 1$ dan $\mathrm{X} 2$ menjadi persamaan berikut:

$$
\hat{\mathbf{Y}}=\mathbf{1 1 , 7 2 6}+\mathbf{0 , 4 1 7} \mathrm{X} 1+\mathbf{0 , 4 4 5} \mathrm{X} 2
$$

Dari persamaan regresi di atas maka dapat disimpulkan bahwa jika Kesiapan Belajar (X1) dan Motivasi Belajar (X2) bernilai 0, maka Hasil Belajar sebesar konstanta a atau 11,726. Sedangkan kesiapan Belajar (X1) dan Motivasi Belajar (X2) memiliki koefisien regresi masingmasing terhadap Hasil Belajar $(Y)$ sebesar $b_{1}(0,417)$ dan $b_{2}(0,445)$ artinya setiap kenaikan 1 poin pada Kesiapan Belajar (X1) maka akan menyebabkan kenaikan Hasil Belajar (Y) sebesar 0,417, juga apabila terdapat kenaikan setiap kenaikan 1 poin pada Motivasi Belajar (X2) maka akan menyebabkan kenaikan Hasil Belajar (Y) sebesar 0,445 .

\section{Korelasi Product Moment}

Dengan menggunakan SPSS, koefisien korelasi parsial masing-masing variabel X1 dan $\mathrm{X} 2$ terhadap Y diperoleh:

\section{Tabel Korelasi}

\begin{tabular}{llcc} 
& $\begin{array}{c}\text { KESIAPAN_ } \\
\text { BELAJAR }\end{array}$ & $\begin{array}{c}\text { MOTIVASI_ } \\
\text { BELAJAR }\end{array}$ \\
\hline $\begin{array}{l}\text { HASIL_BELAJA } \\
\text { R Pearson Correlation }\end{array}$ & $.743^{* *}$ & $.780^{* *}$ \\
& Sig. (2-tailed) & .000 & .000 \\
& $\mathrm{~N}$ & 92 & 92 \\
\hline Sumber: Penulis (data diolah) & &
\end{tabular}

Sumber : Penulis (data diolah)

Dari data di atas, dapat diuraikan Korelasi Product Moment Pearson untuk X1 (Kesiapan Belajar) terhadap Y (Hasil Belajar) ialah: $r x_{1} y=0.743$. Sedangkan Korelasi untuk X2 (Motivasi Belajar) terhadap Y (Hasil Belajar) ialah $r x_{1} y=0.780$

Dari data di atas dapat disimpulkan terdapat korelasi hubungan yang kuat antara masingmasing variabel Kesiapan Belajar (X1) dan Motivasi (X2) terhadap Hasil Belajar (Y). 
Duconomics Sci-meet Vol. 1

Juli, 2021

\section{Uji Determinasi $\left(R^{2}\right)$}

Dengan menggunakan SPSS untuk menghitung uji Determinasi $\left(\mathrm{R}^{2}\right)$ maka diperoleh data hasil perhitungan sebagai berikut:

\begin{tabular}{|c|c|c|c|c|c|c|}
\hline & \multicolumn{6}{|c|}{ Model Summary } \\
\hline \multirow[b]{2}{*}{ Model } & & & & & \multicolumn{2}{|c|}{ Change Statistics } \\
\hline & $\mathrm{R}$ & R Square & $\begin{array}{l}\text { Adjusted R } \\
\text { Square }\end{array}$ & $\begin{array}{l}\text { Std. Error } \\
\text { of the } \\
\text { Estimate }\end{array}$ & $\begin{array}{l}\text { R Square } \\
\text { Change }\end{array}$ & F Change \\
\hline 1 & $.949^{\mathrm{a}}$ & 900 & $.898=11$ & 1.90390 & .900 & 401.052 \\
\hline
\end{tabular}

Besarnya nilai $\mathrm{R}^{2}$ berada diantara 0 (nol) dan 1 (satu) yaitu $0<\mathrm{R}^{2}<1$. Jika nilai $\mathrm{R}^{2}$ semakin mendekati 1 (satu) maka model tersebut baik dan pengaruh antara variabel bebas $\mathrm{X}$ dengan variabel terikat $\mathrm{Y}$ semakin kuat (erat hubungannnya). Dari data di atas diperoleh $\mathrm{R}^{2}=$ 0,900 maka dapat disimpulkan Variabel Kesiapan Belajar dan Motivasi Belajar (X1 dan X2) sangat erat Hubungannya terhadap Hasil Belajar (Y).

\section{Pengujian Hipotesis}

Uji Simultan atau Uji $(F)$

Berdasarkan Perhitungan menggunakan SPSS didapatkan hasil sebagai berikut:

ANOVA ${ }^{\mathrm{a}}$

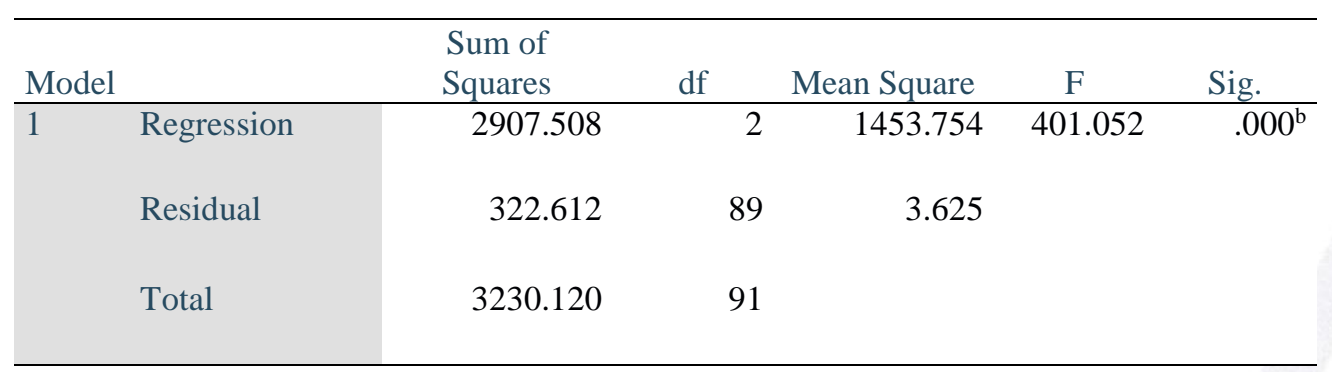

Dependent Variable: HASIL_BELAJAR

Predictors: (Constant), MOTIVASI_BELAJAR, KESIAPAN_BELAJAR

Dari tabel F statistik menunjukan bahwa $\mathrm{t}_{\text {tabel }}$ pada $\alpha=5 \%$ untuk uji dua pihak $(\mathrm{dk})=\mathrm{n}$ - 2 - 1 didapat angka $F_{\text {tabel }}$ yaitu 0,117. Kemudian dibandingkan dengan dari hasil perhitungan dengan SPSS sesuai tabel diatas diperoleh $F$ hitung yaitu 401,052. Maka $F_{\text {hitung }}>F_{\text {tabel }}(401,052$ $>0,117$ ) Oleh karena itu Ho ditolak dan Ha diterima. Maka dapat disimpulkan bahwa Ada Pengaruh Kesiapan Belajar dan Motivasi Belajar secara berasama-sama Terhadap Hasil Belajar di SMPN 1 Tarumajaya Bekasi.

\section{Uji signifikansi Parsial (uji t)} berikut:

Nilai thitung diperoleh dengan perhitungan menggunakan SPSS dengan hasil sebagai

\section{Tabel Uji t}

\begin{tabular}{|c|c|c|c|c|c|}
\hline \multirow{2}{*}{ Model } & \multicolumn{2}{|c|}{$\begin{array}{l}\text { Unstandardized } \\
\text { Coefficients }\end{array}$} & $\begin{array}{l}\text { Standardized } \\
\text { Coefficients }\end{array}$ & \multirow{2}{*}{$\mathrm{t}$} & \multirow{2}{*}{ Sig. } \\
\hline & $\mathrm{B}$ & $\begin{array}{l}\text { Std. } \\
\text { Error }\end{array}$ & Beta & & \\
\hline 1 (Constant) & 11.726 & 2.461 & & 4.765 & .000 \\
\hline
\end{tabular}


Merdeka Belajar dan Tantangan Ekonomi dalam Menyongsong Era Society 5.0

a. dependent variable: hasil_belajar

Dari tabel di atas, diketahui nilai $t_{\text {hitung }}$ untuk variabel kesiapan belajar ialah 16,106 sedangkan $\mathrm{t}$ hitung untuk variabel Prestasi Belajar ialah 17,617. Untuk $\mathrm{t}$ tabel diperoleh angka $\mathrm{t}_{\text {tabel }}=1,990$

a) Pengaruh Variabel Kesiapan Belajar Terhadap Hasil Belajar

Dari hasil perhitungan diperoleh thitung $>$ ttabel $(16,106>1,990)$ maka Ho ditolak dan Ha diterima. Maka dapat disimpulkan bahwa secara parsial terdapat pengaruh yang positif dan signifikan antara variabel X1 (Kesiapan Belajar) terhadap variabel Y (Hasil Belajar) siswa kelas VIII SMPN 1 Tarumajaya Bekasi.

b) Pengaruh Variabel Motivasi Belajar Terhadap Hasil Belajar

Dari hasil perhitungan diperoleh thitung>ttabel $(17,617>1,990)$ sehingga Ho ditolak dan Ha diterima. Maka dapat disimpulkan bahwa secara parsial terdapat pengaruh yang positif dan signifikan antara variabel X2 (Motivasi Belajar) terhadap variabel Y (Hasil Belajar) Siswa kelas VIII SMPN 1 Tarumajaya Bekasi.

\section{Pembahasan}

Berdasarkan hasil perhitungan, pengaruh kesiapan belajar ditunjukan adanya korelasi yang kuat antara variabel kesiapan belajar dan hasil belajar yakni sebesar 0,743 atau 74,3\%, kemudian diperoleh nilai koefisiensi regresi (b) sebesar 0,417. Angka koefisien regresi ini menjelaskan apabila Kesiapan Belajar Siswa Meningkat 10 poin angka maka secara positif akan meningkatkan hasil belajar siswa sebanyak 4 poin. Pada taraf signifikansi 5\%, dapat diketahui $t_{\text {hitung }}$ sebesar 16,106 dengan nilai signifikansi sebesar 0,000 karena koefisien regresi mempunyai nilai positif dan nilai signifikansi $(\mathrm{p})<$ 0,05 maka dapat disimpulkan Ada pengaruh yang positif kesiapan belajar terhadap hasil belajar IPS siswa kelas VIII di SMPN 1 Tarumajaya Bekasi.

Hasil penelitian ini diperkuat oleh pendapat Sutiah (2016:14) yang mengemukakan bahwa:

a. Individu akan dapat belajar dengan baik apabila tugas yang diberikan kepadanya sesuai dengan kesiapan (kematangan usia, kemampuan, minat, dan latar belakang pengalamannya)

b. Kesiapan belajar harus dikaji lebih dulu untuk memperoleh gambaran kesiapan belajar peserta didik dengan jalan menguji kesiapan atau kemampuan.

c. Jika individu kurang siap melaksanakan suatu tugas belajar, maka akan menghambat proses pengaitan pengetahuan baru kedalam struktu kognitif yang dimilikinya.

d. Kesiapan belajar mencerminkan jenis dan taraf kesiapan untuk menerima suatu yang baru dalam membentuk dan mengembangkan kemampuan lebih matang.

e. Bahan dan tugas-tugas belajar akan sangat baik kalau divariasi sesuai denga faktor kesiapan kognitif, afektif, dan psikomotorik peserta didik yang akan belajar.

Pendapat lain oleh Slameto (2010:59) yang mengemukakan bahwa kesiapan perlu diperhatikan dalam proses belajar karena saat siswa sudah memiliki persiapan belajar maka hasil belajarnya akan lebih baik. Kesiapan diperlukan dalam proses belajar mengajar karena dalam kondisi siap siswa akan cenderung lebih mudah untuk mengikuti pembelajaran.

Penelitian sebelumnya yang dilakukan oleh Endah Widiarti (2018) dengan judul "Pengaruh Motivasi Belajar Dan Kesiapan Belajar Siswa Terhadap Hasil Belajar Mata Pelajaran Ekonomi Siswa Kelas X Ilmu-Ilmu Sosial Di Sma Negeri 2 Banguntapan, Bantul yang relevan dengan penelitian ini menunjukan adanya pengaruh positif kesiapan belajar siswa terhadap hasil belajar siswa.

Hasil penelitian lain yang memperkuat penelitian dilakukan oleh Vivo Sintia B. (2017) dengan Judul "Pengaruh Kesiapan Belajar Siswa terhadap Hasil Belajar Pada Mata Pelajaran Ekonomi Kelas X di SMA Bina Jaya Palembang” dengan taraf signifikansi 5\% atau dengan 
taraf kepercayan 95\% dengan metode deskriptif korelasional. Berdasarkan kesiapan belajar rata-rata sebesar 75,62\% sedangkan analisis hasil belajar (Mid) siswa rata-rata 74,25, dengan persamaan Regresi $Y$ ' $=68,11+0,13 \mathrm{X}$ dari pengujian uji " $\mathrm{t}$ " menghasilkan $t_{\text {hitung }}=2,6>t_{\text {tabel }}$ $\alpha 0,05 / \mathrm{dk} 118=1,671$ maka pada pengujian tersebut $\mathrm{Ha}$ diterima dan $H 0$ ditolak yang berati diantara kesiapan belajar ada pengaruh secara signifikan terhadap hasil belajar.

Kesiapan belajar menyangkut kematangan pertumbuhan fisik dan psikis, intelegensia, latar belakang pengalaman, hasil belajar yang baku, motivasi, persepsi dan faktor-faktor yang memungkinkan seseorang dapat belajar. Proses belajar sangat dipengaruhi oleh kesiapan individu sebagai subjek yang melakukan kegiatan belajar.

Berdasarkan hasil analisis dan perhitungan statistik, pengaruh Motivasi belajar terhadap Hasil Belajar IPS menunjukan adanya korelasi yang kuat antara variabel kesiapan belajar dan hasil belajar yakni sebesar 0,780 atau 78,0\%, kemudian diperoleh nilai koefisiensi regresi (b) sebesar 0,445. Angka koefisien regresi ini menjelaskan apabila Motivasi Belajar Siswa Meningkat 10 poin angka maka secara positif akan meningkatkan hasil belajar siswa sebanyak 4,45 poin. Pada taraf signifikansi 5\%, dapat diketahui thitung sebesar 17,617 dengan nilai signifikansi sebesar 0,000 karena koefisien regresi mempunyai nilai positif dan nilai signifikansi $(\mathrm{p})<0,05$ maka dapat disimpulkan ada pengaruh yang positif motivasi belajar terhadap hasil belajar IPS siswa kelas VIII di SMPN 1 Tarumajaya Bekasi.

Hasil penelitian ini sejalan dengan pendapat Hamzah B. Uno yang dikutip oleh Badaruddin (2015:19), hakikat motivasi belajar adalah dorongan internal dan eksternal pada siswa yang sedang belajar untuk mengadakan perubahan tingkah laku, pada umumnya dengan beberapa indikator atau unsur yang mendukung. Hal itu yang memiliki peranan besar dalam kesuksesan mencapai tujuan belajar.

Lebih lanjut Hamzah B. Uno menjelaskan peranan penting motivasi dalam belajar diantaranya sebagai berikut:

a. Memberikan penguatan terhadap belajar.

Motivasi memperkuat seseorang dalam pembelajaran jika dihadapkan pada suatu masalah

yang harus dipecahkan. Motivasi akan mendorong seseorang untuk mencari cara, alat atau apa pun yang dapat membatunya memecahkan masalah tersebut.

b. Memperjelas tujuan belajar.

Motivasi berkaitan erat dengan kemaknaan belajar. Motivasi belajar seseorang akan

bertambah jika sesuatu yang dipelajarinya sedikitnya sudak dapat diketahui atau dinikmati manfaatnya.

c. Menentukan keajegan dan ketekunan belajar.

Seseorang yang termotivasi untuk belajar sesuatu akan berusaha mempelajarinya dengan baik dan tekun, dengan harapan memperoleh hasil yang lebih baik.

Adanya pengaruh Motivasi terhadap Hasil Belajar juga diperkuat oleh Penelitian yang relevan sebelum penelitian ini juga menunjukan hasil Ada Pengaruh Motivasi Belajar terhadap Hasil Belajar. Diantaranya penelitian Oleh Rafiqah M. (2013) dengan judul "Pengaruh Motivasi Belajar Siswa Terhadap Prestasi Belajar Siswa". Berdasarkan perhitungan regresi linier sederhana tentang variabel motivasi belajar didapatkan hasil nilai korelasi $R$ adalah 0,610 . Nilai ini dapat diinterpretasikan bahwa hubungan kedua variabel penelitian ada di kategori sedang. Dan diperoleh nilai R Square atau koefisien determinasi (KD) yang menunjukkan seberapa bagus model regresi yang dibentuk oleh interaksi variabel bebas dan variabel terikat. Nilai KD yang diperoleh adalah 0,753 yang dapat ditafsirkan bahwa variabel bebas memiliki pengaruh kontribusi sebesar 0,753 atau sebesar $75,3 \%$ terhadap variabel $Y$ dan 24,7\% lainnya dipengaruhi oleh faktor-faktor lain diluar variabel Y. dari hasil perhitungan yang telah dilakukan maka Ho ditolak dan Ha diterima yaitu terdapat pengaruh motivasi belajar terhadap prestasi belajar pada siswa siswi kelas XI SMA Negeri 2 Metro tahun pelajaran 2012-2013.pada 


\section{4|}

Merdeka Belajar dan Tantangan Ekonomi dalam Menyongsong Era Society 5.0

pengujian tersebut $\mathrm{Ha}$ diterima dan $\mathrm{Ho}$ ditolak yang berarti diantara kesiapan belajar ada pengaruh secara signifikan terhadap hasil belajar.

Hasil dari penelitian ini mendapatkan $F_{\text {hitung }}>F_{\text {tabel }}(401,052>0,117)$ Oleh karena itu Ho ditolak dan Ha diterima. Maka dapat disimpulkan bahwa Ada Pengaruh Kesiapan Belajar dan Motivasi Belajar secara berasama-sama Terhadap Hasil Belajar di SMPN 1 Tarumajaya Bekasi.

Hasil penelitian ini diperkuat dengan penelitian sebelumnya dilakukan oleh Endah Widiarti (2018) dengan judul "Pengaruh Motivasi Belajar Dan Kesiapan Belajar Siswa Terhadap Hasil Belajar Mata Pelajaran Ekonomi Siswa Kelas X Ilmu-Ilmu Sosial Di Sma Negeri 2 Banguntapan, Bantul. Hasil penelitian menunjukan Terdapat pengaruh Motivasi Belajar dan Kesiapan Belajar Siswa secara bersama-sama terhadap Hasil Belajar Mata Pelajaran Ekonomi Siswa Kelas X Ilmu-Ilmu Sosial di SMA Negeri 2 Banguntapan, Bantul. Hal ini ditunjukkan dengan nilai Fhitung sebesar 180,033 dengan nilai signifikansi $\mathrm{F}$ sebesar 0,000. Karena nilai signifikansi $\mathrm{F}<0,05$ maka terdapat pengaruh motivasi belajar dan kesiapan belajar siswa secara bersama-sama terhadap hasil belajar mata pelajaran ekonomi.

\section{SIMPULAN}

Berdasarkan hasil pembahasan, makan penelitian ini dapat disimpulkan sebagai berikut:

1. Ada pengaruh Kesiapan Belajar dan Motivasi Belajar secara simultan atau bersama-sama terhadap Hasil Belajar Siswa Kelas VIII di SMPN 1 Tarumajaya Bekasi dengan nilai $\mathrm{F}$ hitung $>\mathrm{F}_{\text {tabel }}$ yakni 401,052 > 0,117.

2. Ada pengaruh Kesiapan Belajar secara parsial atau sendiri terhadap Hasil Belajar Siswa kelas VIII di SMPN 1 Tarumajaya Bekasi dengan nilai $t_{\text {hitung }}>t_{\text {tabel }}$ yakni 16,106 >1,990.

3. Ada pengaruh Motivasi Belajar secara parsial atau sendiri terhadap Hasil Belajar Siswa Kelas VIII di SMPN 1 Tarumajaya Bekasi dengan $t_{\text {hitung }}>t_{\text {tabel }}$ yakni 17,617 > 1,990.

\section{DAFTAR PUSTAKA}

Al-Farabi, Mohammad. (2018). Pendidikan Orang Dewasa dalam Al-Qur'an. Jakarta: Kencana.

Badaruddin, Achmad. 2015. Peningkatan Motivasi Belajar Melalui Konseling Klasikal. Jakarta: CV Abe Kreatifindo

Jihad, A. dan Abdul Haris. (2012). Evaluasi Pembelajaran. Yogyakarta: Multi Prassindo.

Mulyana E. (2006). Implementasi Kurikulum 2004: Panduan Belajar KBK. Bandung: Remaja Rosdakarya.

Rafiqah, Mar'atur. 2013. Pengaruh Motivasi Belajar Siswa Terhadap Prestasi Belajar Siswa. Jurnal Bimbingan dan Konseling (ALIBKIN). 2 (2).

Rusman. (2011). Model-Model Pembelajaran: Mengembangkan Profesionalisme Guru. Jakarta: Rajawali Pers.

Sardiman, A.M. (2004). Interaksi dan Motivasi Belajar Mengajar. Jakarta: Bumi Aksara.

Slameto. (2010). Belajar dan Faktor-Faktor yang Mempengaruhinya. Jakarta: Rineka Cipta.

Supardi. (2012). Aplikasi Statistika dalam Penilaian Buku Tentang Statistika yang paling Kompherensif. Jakarta: Ufuk Press.

Sutiah. (2016). Teori Belajar dan Pembelajaran. Sidoarjo: Nizami Learning Center

Uno, Hamzah B. (2011). Teori Motivasi dan Pengukurannya. Jakarta: PT Bumi Aksara Bandung PT Remaja Rosdaka Karya.

Widiarti, Endah. 2018. Pengaruh motivasi belajar dan kesiapan belajar siswa terhadap hasil belajar mata pelajaran ekonomi siswa. Kelas x ilmu-ilmu sosial di sma negeri 2 banguntapan Bantul. UNY Yogyakarta:

Winkel, W.S. (1998). Psikologi Pengajaran. Jakarta : PT. Gramedia. 